\title{
A critical review of anticancer properties of Withania somnifera (L.) Dunal with respect to the biochemical mechanisms of its phytochemical constituents
}

\author{
Rutwick Surya $\mathrm{U}^{1}$, Poornananda M Naik ${ }^{2}$, Vinayak Upadhya ${ }^{3}$ \& Praveen $\mathrm{N}^{1^{*}}$ \\ ${ }^{1}$ Department of Life Sciences, CHRIST (Deemed to be University), Hosur Road, Bengaluru 560 029, Karnataka, India \\ ${ }^{2}$ Department of Botany, Karnatak University, Dharwad 580 003, Karnataka, India \\ ${ }^{3}$ Department of Forest Products and Utilization, College of Forestry (University of Agricultural Sciences, Dharwad), Banavasi Road, Sirsi 581 \\ 401, Karnataka, India \\ *Email: praveen.n@christuniversity.in
}

\section{ARTICLE HISTORY}

Received: 21 September 2020

Accepted: 23 December 2020

Published: 01 April 2021

\section{KEYWORDS}

Anti-cancer activity

Phytochemistry

Withania somnifera

Withaferin-A

Withanolides

Withanolide-A

\section{ABSTRACT}

Cancer is a leading cause of mortality worldwide, the conventional chemotherapeutic drugs have been known for their toxicity and numerous side effects. A new approach to treat cancer involves phytochemical drugs. In the present review, anti-cancer activity of a class of steroidal lactones called withanolides obtained from Withania somnifera (L.) Dunal is discussed. The commonly studied bioactive compounds namely withaferin-A, withanoside IV, withanoside $\mathrm{VI}$ and withanolide-A among others obtained from methanolic and chloroform extract of the leaves and various alcoholic, aqueous and chloroform extract of roots have shown inhibition to various human cancer cell lines including skin, breast, colon, prostate, liver, ovary, cervical and lung. Prominent mechanisms of action include induction of apoptosis by NOS upregulation, ROS production and NBS2 or COX-2 inhibition; cytotoxicity by humoral and cell mediated immune response, activation of p53 and pRB and inhibition of various viral oncoproteins; cell cycle arrest by Cdc2 facilitated mitotic catastrophe, cyclin-D1 down-regulation and inhibition of transcription factors. Cancers are also controlled by inhibition of angiogenesis and metastasis of the tumor cells. In addition to anti-tumorogenic properties, W. somnifera also holds properties that make it a potential adjuvant in integrated cancer therapeutics and in enhancing the effectiveness of ongoing radiation therapy.

\section{Introduction}

One of the most common forms of medication involves phytotherapy; plants show a vast molecular diversity and produce numerous therapeutic phytochemicals. Over $60 \%$ of the people across the world rely on phytochemicals to cure various diseases. Moreover, currently, extensive studies are being conducted to develop and screen new drugs in phytotherapy (1). It is essential to evaluate and screen more such phytochemicals for pharmaceutical purposes (2). Most of these phytotherapeutic drugs are made out of phytochemicals mainly comprising lactones and alkaloids obtained from root, stem, leaves and other parts of a plant (3).
In fact, various herbal plants were reported to be historically used as prophylactic agents for treatment of cancer in India, Greece, China and Egypt (4). Indian winter cherry is also known as Indian ginseng due to resemblance in its usage with Chinese Panax ginseng. It is more commonly referred to as Ashwagandha (meaning "horse-smell") because the smell of its roots resembles that of a horse (5). Its scientific name Withania somnifera (L.) Dunal originates from Latin, and it means "sleep-inducing" or sedative $(3,6)$. follows:

The taxonomic position of $W$. somnifera is as

Kingdom - Plantae (Plants)

Subkingdom - Tracheobionta (Vascular plants)

(C) Surya et al (2021). This is an open-access article distributed under the terms of the Creative Commons Attribution License, which permits unrestricted use, distribution and reproduction in any medium, provided the original author and source are credited (https://creativecommons.org/licenses/by/4.0/).

To cite this article: Surya U R, Naik P M, Vinayak U, Praveen N. A critical review of anticancer properties of Withania somnifera L. Dunal with respect to the biochemical mechanisms of its phytochemical constituents. Plant Science Today. 2021;8(2):236-249. https://doi.org/10.14719/pst.2021.8.2.969 


$\begin{array}{ll}\text { Super division } & \text { - Spermatophyta (Seed plants) } \\ \text { Division } & \text { - Angiosperms } \\ \text { Class } & \text { - Dicotyledoneae } \\ \text { Order } & \text { - Solanales / Tubiflorae } \\ \text { Family } & - \text { Solanaceae } \\ \text { Genus } & - \text { Withania } \\ \text { Species } & - \text { W. somnifera }\end{array}$

W. somnifera is described as a small, woody, erect and evergreen shrub of about 2 feet tall belonging to the Nightshade family. The roots of $W$. somnifera are whitish brown in color and stout fleshy in appearance. Leaves are simple, with ovate margin and glabrous surface; they are relatively smaller and opposite when closer to the flower. The flowers borne by $W$. somnifera are small, inconspicuous and greenish to lubrid yellow in color; the axillary flower shows umbellate cyme inflorescence. Its ripened fruits are globose, orange red berries enclosed within

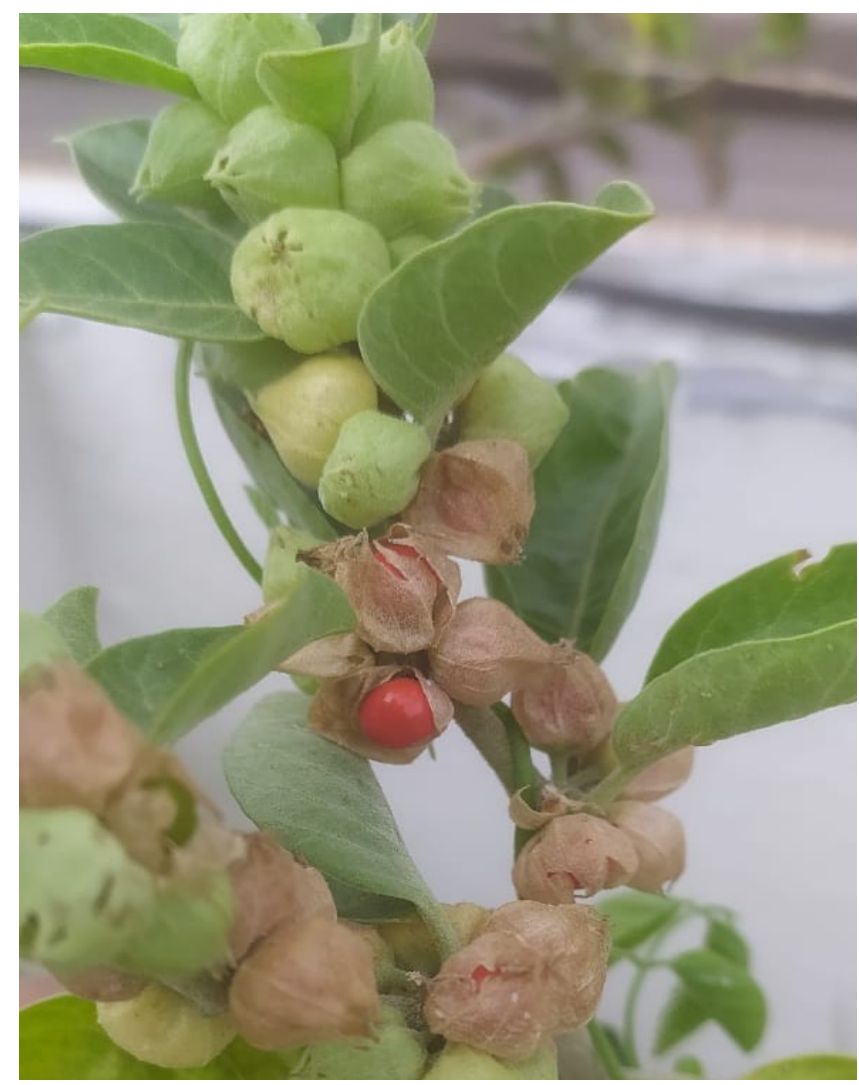

Fig. 1. Morphology of Withania somnifera (L.) Dunal during fruiting stage.

persistent calyx (Fig. 1) and shows properties to coagulate milk. The seeds appear yellow and reniform.

The origin of $W$. somnifera can be traced back in the Asian countries like India, Pakistan, Afghanistan and other dry regions like South Africa. It grows in Africa, Mediterranean region and India. In India, it's found to grow in dry regions of Manasa, Neemuch, Jhawad, Hehsils of Mandsaur, districts of Madhya Pradesh, Punjab, Sindh and Rajasthan (6).

\section{Pharmacological activity of $W$. somnifera}

Various steroidal lactones obtained from root, stem and leaves of $W$. somnifera show therapeutic properties that affect the immune system, circulatory system, CNS etc (7). It is a well-known sedative, hypnotic/narcotic and has the ability to boost energy. Studies have shown that $W$. somnifera extracts have positive effects on overall health, especially during pregnancy and increase non-specific resistance against various physical, chemical and biological agents (8). It has been used to treat arthritis, venom toxins, muscle strain, fatigue, skin infections, rheumatoid joint inflammation, aches and rheumatism (9).

It has been prominently used as antiulcerogenic, anti-diabetic, anti-Parkinson's, antifungal, anti-malarial, anti-hypertension, antiinflammatory, anti-microbial, anti-stress, anti-ageing, anti-fatigue, analgesic, immunomodulatory, hepatoprotective, free radical scavenging, detoxifying, neurogenerative, chondroprotective and cardio-protective agent. It also acts as an antidepressant, anti-coagulant and anti-oxidant and is a well-known rejuvenator (9).

\section{Phytochemistry and bioactive compounds obtained from $W$. somnifera}

Major active compounds among the $W$. somnifera phytochemicals are over 20 alkaloids including anaferin, cuscohygrine, anahygrin and steroidal lactones such as withanolides, withaferin, withanamides, withanosides (Fig. 2), withanolide glycosides, liganamides and steroidal saponins (1013). Withanolides are a family of structurally complex steroidal lactones which act as potential drugs and aid in various biological and physiological activities (14). They are characterized by an ergostane skeleton whose C-22 and C-26 are oxidized to form $\delta$ lactones with 2-ene-1-one in ring $\mathrm{A}$ of the steroid (15). They are given the name 22-Hydroxy ergostane-26-oic acid 26,22-d-lactone. Steroidal alkaloids and steroidal lactones (withanolides) are major constituents of alcohol extract of $W$. somnifera (16). Withanolide biosynthesis shows high levels of tissue specificity. The highest abundance of withaferin-A is found to be in leaf tissue followed by the bark, stem and roots. Conversely, withanolide-A is abundantly biosynthesized in roots followed by other tissues. Therefore in general both root and leaf tissues are considered to study the biosynthesis of withanolides (16).

There are over 40 known withanolides of which 12 major withanolides obtained from $W$. somnifera are withaferin A, sitoindosidic, 25-hydroxy-27desoxywithaferin-A, 2-3 dihydrowithaferin, Physagulin-D, PhysagulinD(1->6)- $\beta$-D-glucopyranosyl(1->4)- $\beta$-D-glcopyranoside,27-O- $\beta$-D-

glucopyranoylphysagulin $\mathrm{D}$, withanoside IV, 27-O- $\beta$ D-glucopyranosylviscosalactone B, 4,16-dihydroxy$5 \beta, 6 \beta$-epoxyphysagulin $\mathrm{D}$, viscosalactone $\mathrm{B}$, and diacetylwithaferin A. Out of these the most studied are withaferin A, withanolide A and withanone (17).

Other plants reported to produce withanolides are mostly from Solanaceae and rarely from 
Taccaceae, Fabaceae and Lamiaceae. Within cell under minimal adversities. Most of the Solanaceae, species from Withania genus are the chemotherapeutic agents target various unique

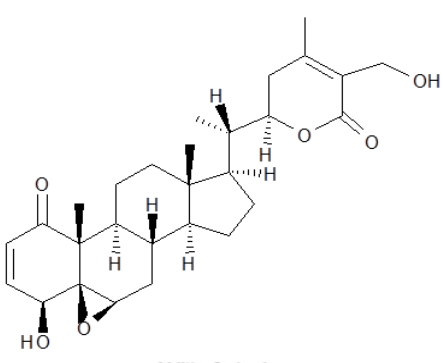

Withaferin $\mathrm{A}$
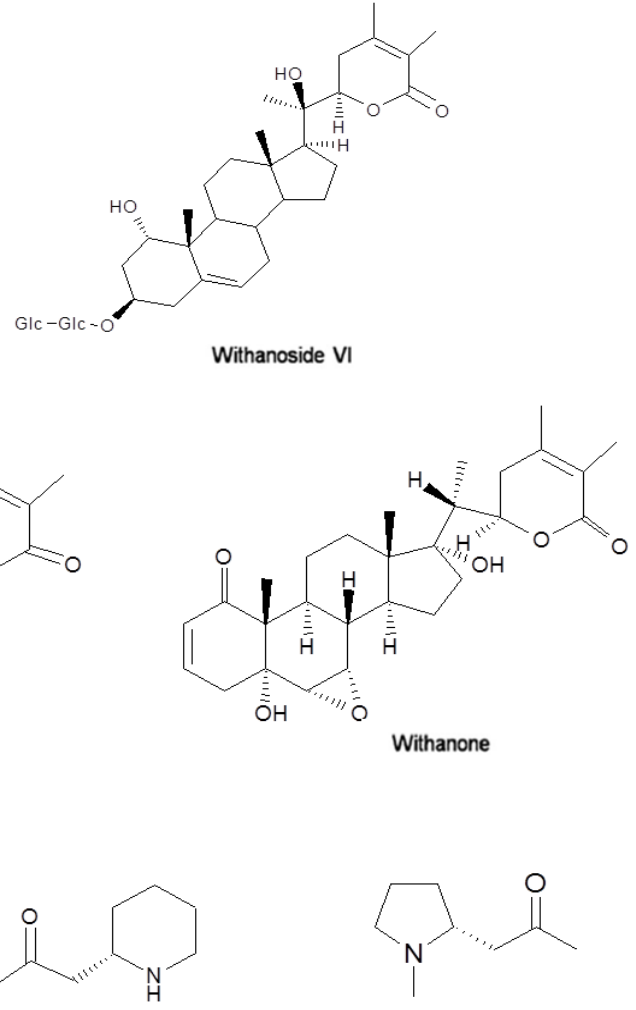

Hygrine
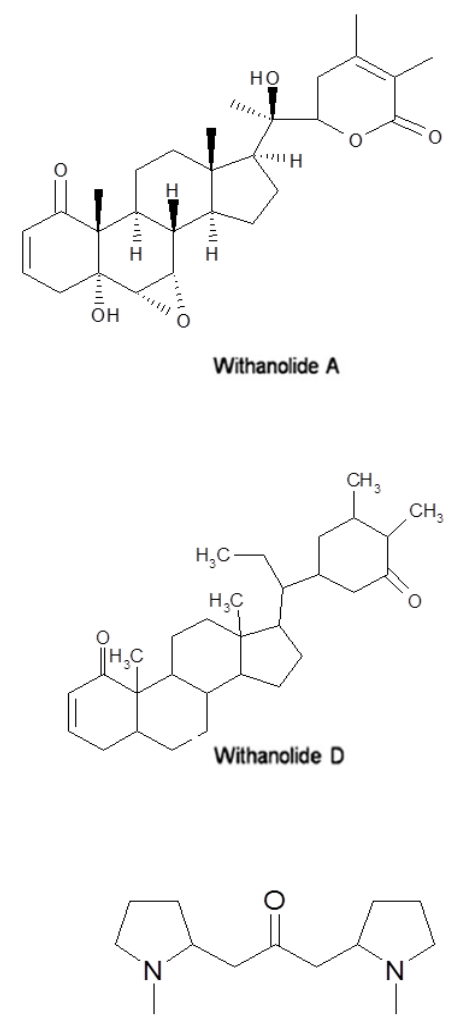

Cuscohygrine

Fig. 2. Some important phytochemical constituents of Withania somnifera (L.) Dunal.

major producers, but 14 other reported withanolide producing genera are Acnistus, Datura, Deprea, Dunalis, Iochroma, Jaborosa, Lycium, Nicandra, Physalis, Salpichroa, Tubocapsicum, Discopodium, Treconaetes and Witheringia (18-21).

\section{Cancer and its treatment}

Cancer is a group of heterogeneous hyper proliferative disorder that causes alterations in cellular signaling pathways leading to tumorogenesis due to uninhibited proliferation and deregulation of cell cycle and its apoptosis mechanisms (22). Various hallmarks of cancer are transformation, apoptotic dysregulation, proliferation, invasion, metastasis, angiogenesis, replicative immortality and tumor promoting inflammations (23). Self-sufficiency in growth signaling, metastasis, alteration of cellular bioenergetics and invasion of immune detaching tissue, leading to alteration in apoptosis which causes apoptosis (24), progression of this tumor is due to gene instability and mutations (25). Across the world, cancer is a major factor contributing to increased death rates. Cancers that show maximum death rates are colorectal, stomach, breast, lung and prostate cancer (3). Only $5 \%$ of all cancers have hereditary causes; while the rest are due to either internal or external environmental factors (10).

Based on the common hallmarks of cancer, most treatment techniques selectively interfere with replication of tumor and regulate homeostasis of the cancer hallmarks in their course of treatment (26). Common cellular pathways that are targeted include p53 signaling, GM-CSF signaling, death receptor signaling, apoptosis signaling pathways respectively and the G2-M DNA damage regulation pathway (27). Common therapeutic approaches to treat cancer are surgical removal of tumor, radiation therapy, chemotherapy and other specific targeted therapies. Biotransformation of chemotherapeutic drugs in the liver generates toxic and highly reactive metabolites (28). While targeted therapies are most efficient to treat benign tumors with least noted side effects, they are difficult to treat metastatic cancers. Various plants are known to be direct sources to major chemotherapeutic drugs against cancer worldwide. Catharanthus roseus is a source for vinblastine and vincristine, Podophyllum spp. are source for podophyllotoxin and its derivatives etoposide and teniposide, Taxus brevifolia is a source for paclitaxel (29). While many plants are an indirect source to major chemotherapeutic drugs, vinorelbine and doctaxel are semi synthetic derivative of Taxus baccata; irinotecan and topotecan are semi synthetic derivatives of Camptotheca acuminata (30-32).

\section{Major active compounds in anti-cancer activity}

Studies show that withanolides obtained from roots and leaves of $W$. somnifera are cytotoxic to tumor cells $(33,34)$ and possess immunomodulatory and neuroprotective properties $(1,3,35-41)$. In fact, most withanolides inhibit various hallmarks of cancer and 
are anti-proliferative, anti-metastatic, antiangiogenic, anti-invasive and pro-apoptotic (42). Most of these phytochemicals are classified under chemotype III $(43,44)$. Withanolides are also biosynthesized in other Withania spp. such as $W$. aduensis, $W$. riebeckii and $W$. coagulans (42); as well as root and leaf extracts of non Withania spp. such as Tubocapsicum anomalum. However, only 2 species that show economic and medicinal significance in terms of amount of withanolide synthesized, its composition, ease of extraction and desired bioactivity are $W$. somnifera and $W$. coagulans (41).

A study identified inhibitory concentration in $\mu \mathrm{g} / \mathrm{ml}$ of a mixture of withanolide-A for $50 \%$ reduction of lung, CNS, breast and colon cancer cells as $0.24 \pm 0.01$ to $11.6 \pm 1.9$ respectively for withaferin $\mathrm{A}$ and its derivatives, and $0.32 \pm 0.05$ to $0.47 \pm 0.15$ for visosalactone $B$ and $7.9 \pm 2.9$ to $17.3 \pm$ 3.9 for 27-0-glucoside derivative. No inhibition was seen in Physagulin D (45).

The major known anti tumorogenic active compound is a withanolide called withaferin-A (46). Studies have demonstrated various mechanisms of anti-tumor activity by withaferin-A involving activation of p53 and ROS signaling (7, 34, 47), increasing intracellular antioxidant levels (48), induction of apoptosis (49-52), inhibition of activation of NF-KappaB (53), inhibition of notch signaling (54, 55), cytoskeletal architecture alteration, angiogenesis inhibition (56), down regulation of cyclin B1, cyclin A, cdk2, expression of p-cdc2 and increase in cellular levels of p-chk1 and p-chk2, all leading to cell cycle arrest. Other mechanisms include down regulation of oncoproteins, p53 induction and accumulation, increase in cellular levels of P-21, decrease in cellular levels of STAT 3, increase in levels of p53 mediated apoptotic markers such as Bcl 2, BAX, caspase 3, cleaved PARP and PAR 4, down-regulation of AKT and EMT signaling, disruption of certain cytoskeletal elements such as actin, vimentin and intermediate filaments (57-60), inhibition of cell proliferation and alteration of cell differentiation (61), cell cycle arrest (rarely at S phase and mostly at G2/M phase), DNA degradation which is a hall mark of apoptosis, inhibition of angiogenesis and metastasis $(62,63)$. Inhibition of external onco-proteins synthesis is also seen in case of oncoproteins E6 and E7 of human papilloma virus predominantly causing cervical cancer (64).

\section{Mechanism of action against cancer}

A recent study demonstrates the detailed mechanism of action of withaferin-A in prostate cancer cell lines of PC-3 and DU-145. Withaferin-A arrests the cell cycle of these tumorogenic cell lines at G2/M phase. The mechanism for this arrest involves upregulation of phosphorylated wee 1, phosphorylated histone H3, P21 and aurora B, with a simultaneous down regulation of cyclin A2, B1 and E2, and phosphorylated cdc 2 Tyr (15). As a result, cellular levels of phosphorylated chk 1 (Ser 345) and chk 2 (Thr 68) decrease. This leads to activation of cdc 2, which in turn facilitates mitotic catastrophe in abnormally duplicated cells by arresting its cycle at $\mathrm{M}$ phase, ultimately causing death of the cell.
General studies with various $W$. somnifera extracts have reported their ability to inhibit enzymes essential for the cell's TCA cycle such as malate dehydrogenase and isocitrate dehydrogenase in test animals with induced colon cancer (65). Myeloid cells are known to regulate tumor progression. Myeloid derived suppressor cells (MDSC) and tumor associated macrophages (TAM) are two of the most common tumor regulating myeloid cells. The growth of tumor is promoted by these MDSCs as they exhibit inherent immunosuppressive abilities. MDSCs suppress tumor specific $\mathrm{T}$ lymphocytes by releasing $\mathrm{T}$ cell suppressive reactive oxygen species (ROS), thereby causing immunosuppression against cancer (66). They also convert macrophages into a tumor enhancing phenotype (67-70). A study demonstrates the in vitro ability of withaferin-A to reduce the secretion of interleukin (IL) 6 , TNP and acytokines, all of which otherwise increase the concentrations of MDSC. As a result, withaferin-A successfully reduces/inhibits the formation of these reactive oxygen species by STAT 3 dependent mechanism. Hence, a tumor rejecting phenotype is achieved by reduction of myeloid cell immune suppression by withaferin-A. In fact, a common approach to immunotherapy of cancer involves the antitumor immune response activation. In most cancer patients, withaferin-A blocks MDSC and inhibits metastasis of tumor, $(71,72)$; it also enhances the activation of tumor reactive cytotoxic $\mathrm{T}$ lymphocytes (73).

A study on human leukemia cell line showed that mitochondrial dependent and mitochondrial independent apoptosis was induced by withaferin-A, thus leading to dysfunction in the cell and subsequent restriction in growth of the tumor (74). A crude extract of $W$. somnifera has the ability to induce the hall mark of apoptosis in a cancer cell line by causing its DNA fragmentation (75). Another known mechanism of cancer proliferation is the activity of telomerase; non-cancerous cells' life span is regulated by telomere shortening. Tumor cells overcome this mortality by activation of telomerase which adds a sequence of TTAGGG at telomeric ends thereby allowing the cells to proliferate indefinitely (76). Even cancerous cells that don't contain telomere have shown alternative methods to increase the telomere length. Glioblastoma multiforme, gastric carcinoma, neuroblastoma, liposarcoma, epithelioid sarcoma, chondrosarcoma, astrocytoma, malignant fibers and histiocytoma are some of the common tumors that have high prevalence of these alternate telomere lengthening mechanisms $(26,77,78)$. In the absence of telomere lengthening, replicative mortality is achieved by DNA damage signals which lead to apoptosis. Hence, telomerase inhibition is a potential cancer therapy.

Withaferin-A inhibits telomerase activity and the subsequent upregulation of DNA damage response due to telomere dysfunction. Studies have also shown that the activity of withaferin-A against alternative mechanisms of telomere lengthening is even more efficient. Withaferin-A causes transcriptional suppression of an MRN complex protein NBS-1 mediated by myc-mad. NBS-1 is an essential component of alternative telomere lengthening (79). 
Conversion of the cellular lipid arachidonic acid to prostaglandins which causes inflammatory response is carried out by enzymes cyclooxygenase (COX) 1 and 2. An inflamed or cancerous cell has high expression of COX 2 (80-82). An effective chemopreventive approach for cancer is to selectively inhibit COX 2, which in turn inhibits COX 1 activity. This selective inhibition of COX 2 is more effective than the conventional non-selective-non-steroidalanti-inflammatory drugs (83). Studies have shown that $W$. somnifera leaf extract possesses excellent ability to selectively inhibit COX 2 (84).

The active compound triethylene glycol present in the aqueous extract of $W$. somnifera leaves can activate tumor suppressor genes like p53 and pRB. In a normal cell, there is an increased degree of phosphorylation of $\mathrm{pRB}$ gene which increases the cellular concentration of cyclin B1; the latter in turn decreases the concentration of cyclin D1. This facilitates normal progression of the cell cycle. In a cancerous cell, pRB is hypophosphorylated which decreases the cellular concentration of cyclin B1, thereby increasing the concentration of cyclinD1; this arrests the cell cycle and cell growth. Triethylene glycol also downregulates MMP 3 and MMP 9, which are metastasis regulators in cancerous cells, while normal cells remain unaffected (9).

\section{Anti-tumorogenic activity of various extracts}

\section{Leaf extract}

Studies on mice assay have shown that the methanolic leaf extract of $W$. somnifera containing withanolide-A, withanoside IV, withaferin-A and withanoside VI is non-toxic and anti-tumorogenic predominantly on neuroblastoma. The cancer inhibition factor of the leaf extract affects apoptosis signaling, death receptor signaling, G2-M phase DNA damage regulation pathway, GM-CFS signaling and most commonly p53 signaling. The methanolic and chloroform leaf extract containing withaferin-A causes nuclear translocation of p53. It also activates p53 pathway and disrupts cell cycle in tumor cells. Some studies have even claimed that p53 induced cell cycle disruption can only be carried out by the leaf extract and not the root extract of $W$. somnifera (7, 85). A study on withaferin-A of the chloroform leaf extract reported that it arrests cell cycle of human osteogenic sarcoma cell lines at G2, G1 and S phases with varying cell fractions. Along with this cancer inhibition factor, the hydroalcholic leaf extract also contains polyphenolic compounds that are known to control various cancer cell lines of the breast, ovary and lung cancers including MCF-7, A549 and PA-1 (86). The aqueous extract of $W$. somnifera leaves activate p53, which in turn increase the concentration of cyclin B1 (9). Another mechanism of anti-cancer activity of the leaf extract is its ability to selectively inhibit COX 2 enzyme activity in tumor cells.

\section{Root extract}

$W$. somnifera chloroform root extracts have shown to contain 1-oxo-5- $\beta, 6$ - $\beta$-epoxy witha-2-enolide and 5,6de-Epoxy-5-en-7-one-17-hydroxy withaferin $\mathrm{A}$. Studies have shown that this active compound down regulates tumor in skin carcinoma cell line due to UV exposure in rats; other reports have shown activity against liver, colon, prostate and breast cancer as well (87). The alcoholic root extract has also shown the ability to inhibit various transcriptional factors such as NF-Kappa B and AP 1 (88). It can also induce mitochondria-mediated cytochrome $\mathrm{C}$ release to activate caspases for apoptosis of cancer cells (89). Studies have also shown the ability of ethanolic, chloroform and aqueous root extract to upregulate Th1 dominant polarization which causes humoral and cell mediated immune response (39), down regulate P34cdc2 expression (90) and bring about nitric oxide synthase induced protein expression, NOS also produces nitric oxide which in turn causes DNA damage and mutation by depurination and ATGC transition (91).

\section{Fruit}

The fruits of $W$. somnifera contain L-asparaginase which is known to inhibit the growth of lymphoblastic leukemia (92). A study involving a crude aqueous extract of the fruit assisted by potassium chloride and ammonium sulphate from which L-asparaginase was isolated by various chromatographic columns and electrophoretic techniques was found to be cytotoxic to human lymphoblastic leukemia cell culture at various inhibitory concentrations (93).

\section{Anti-tumorogenic activity to specific cancer cell lines}

\section{Hepatocellular carcinoma}

Hepatocellular carcinoma is the sixth most common form of cancer and the second largest cause of cancer related mortality in East Asia and Sub-Saharan Africa (93), and hence its control and treatment requires great attention $(94,95)$. Over $80 \%$ of hepatocellular carcinoma cases are seen to occur in East Asia and sub-Saharan Africa (96). Hepatitis C virus causes cirrhosis which is a main cause of hepatocellular carcinoma. The major risk factors of human hepatocellular carcinoma include its late symptom presentation, aggressive proliferation and poor sensitivity to conventional medication, along with multiple side effects $(97,98)$. Common treatment strategies of hepatocellular carcinoma include radiofrequency ablation, liver transplantation, transarterial chemoembolization, radioembolization, curative resection and systemic targeted agents (99); but toxicity, pain, fatigue, anemia, emotional distress are some of the reported side effects of these treatment plans. The above mentioned treatments are also expensive (100). Hence, various herbal plants are used as complementary medicine to reduce the tumor without pain (101). Studies have shown that the use of methanolic and aqueous leaf extract of $W$. somnifera inhibits hepatocellular carcinoma by induction of apoptosis and anti-oxidant activities; it also employs other mechanisms for inhibition of cell proliferation and alteration in cell differentiation (61). The mechanism to restrict tumor proliferation in hepatocellular carcinoma involves withaferin-A mediated upregulation of Bim, t-Bid and caspase 8 (102), all of which cause inhibition of TNF $\alpha$; this in turn causes down regulation of cytokines and other 
proteins involved in systematic inflammation, and hence the inhibition of tumor (56). The aqueous leaf extract also acts against Hep G2 cell line of hepatocellular carcinoma by shrinking and decreasing the viability of the tumor (103).

\section{Skin cancer}

Melanoma is the most aggressive form of cancer causing over $75 \%$ deaths due to cancer across the world. Common chemotherapeutic drugs consumed against melanoma are not target specific and have shown various side effects. Many studies on $W$. somnifera alcoholic (mostly ethanolic and methanolic) root extract have proven it as a target specific treatment for melanoma with no side effects. However, most of these studies have used melanoma induced mouse as a target and very few are conducted on human melanoma cell lines. It is also seen that the efficacy of this root extract against melanoma cells depends on dosage and treatment/incubation time (8). Dimethyl benzanthracene present in $W$. somnifera is known to enhance the activity of antioxidant enzymes like glutathione peroxidase and catalase, which in turn reduce skin carcinogenesis (48).

\section{Breast cancer}

Invasive breast cancer is one of the highest causes of mortality due to cancer. There have been over 232,340 cases of invasive breast cancer and 64,640 cases of non-invasive breast cancer of all breast cancer cases in USA women in 2013. It has also been predicted that African American women are more likely to be affected by invasive breast cancer than other American women. Tumor metastasis in lymph nodes, liver and lungs is the main cause of high mortality in invasive breast cancer (104). 10 to $20 \%$ of all breast cancer cases are triple negative and invasive; it is resistant to most conventional chemotherapeutic drugs and radiation therapy. It is also difficult to treat due to its high metastasis and aggressive proliferation. $W$. somnifera extracts can treat this form of breast cancer effectively $(105,106)$. A study conducted on nude mouse xenografts to treat induced breast cancer of MDA-MB-231 cell line, showed that $W$. somnifera was effective in the treatment. It is also known to induce metastasis in MCF 7 and MDA 231 cell lines of human breast cancer by inhibiting Notch signaling cascades. Withaferin-A also reduced metastasis in triple negative invasive breast cancer (26).

\section{Prostate cancer}

Various studies and surveys have claimed that prostate cancer is the third most common cause of cancer related deaths worldwide and second most common cause of cancer death in United States (107). A common therapeutic approach to reduce the proliferation of prostate cancer is to downregulate androgen synthesis. Hence hormone ablation therapy is the primary treatment for prostate cancer (108). Many cases of castration resistant prostate cancers are now emerging to which primary treatment is ineffective (109). W. somnifera extracts causes downregulation of proinflammatory cytokines, which in turn facilitates the upregulation of P38MAPK,
Caspase 6, Cyclin D1 and p13k, all of which inhibit the growth of tumor in prostate cancer. Another mechanism specifically to prostate cancers of PC-3 and DU-145 cell lines is the ability of withaferin-A to regulate $\mathrm{G} 2 / \mathrm{M}$ phase of the cell cycle and stop the tumorous cell growth (64).

\section{Lung cancer}

Lung cancer is one of the leading causes of mortality due to cancer worldwide with about 1 million deaths per year (110). Conventional chemotherapeutic drugs are often prescribed in any of these 3 combinations, vinblastine and cisplatin along with mitomycin; cyclophosphamide, doxorubicin and methotrexate, procarbazine (111); or vincristine with cisplatin and etoposide (112) or paclitaxel. Studies have shown that withanolides suppress NF-KB and its regulated gene products, which ultimately lead to anticancer activity towards lung cancer cell line NCL-H460. Withaferin-

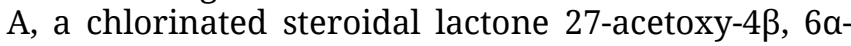
dihydroxy-5 $\beta$-chloro-1-oxowitha-2,24-dienolide and a diepoxywithanolide-5 $\beta, 6 \beta, 14 \alpha, 15 \alpha$, diepoxy $4 \beta, 27-$ dihydroxy-1-oxowith-2,24-dieolide, extracted from the aerial parts of $W$. somnifera have shown growth inhibition towards lung cancer. Withaferin-A is the most cytotoxic one of these three withanolides (113).

\section{Colon and Colorectal cancer}

Colorectal cancer is common worldwide (114), and the fourth leading cause of deaths due to cancer across the world (115). A common treatment approach is chemotherapy, but this mode of treatment is not effective due to drug resistance in tumor cells, as well as high toxicity of these chemotherapeutic drugs towards gastrointestinal tract, skin and bone marrow. STAT 3 is crucial for proliferation of colorectal cancer (116). A study conducted on xenograft of nude mouse for colon and colorectal cancer cell line HCT116 showed that the activation of STAT 3 signaling causes progression of cell cycle, metastasis and angiogenesis, thereby increasing proliferation in the cell culture (117). STAT 3 inhibitions physiologically or chemotherapeutically can cause prevention of colon cancer and promote its apoptosis (118-120). Hence, a therapeutic alternative is to directly inactivate STAT 3 (121). Withaferin-A is seen to block interleukin 6 (IL 6), which induces STAT 3 activation, and thus cease the progression of colon and colorectal cancer tumor proliferation. Other mechanisms by which $W$. somnifera inhibits colon and colorectal cancer proliferation include the generation of cytotoxic reactive oxygen species, inhibition of proteasome, p53 stabilization, endoplasmic reticulum stress induction, activation of p38 MAPk, Akt phosphorylation inhibition, inhibition of notch signaling cascades (122-124).

\section{Cervical cancer}

Various studies have shown that a major cause of cervical cancer is human papilloma virus (HPV) infestation leading to over $70 \%$ of total cervical cancer cases worldwide. HPV 16, 18, 31 and 33 are mainly the causative HPV for cervical cancer (125). Tumor suppressor proteins, p53 and pRb which are essential for cell cycle regulation and protection of genome integrity (126) are inactivated by E6 and E7 
viral oncoproteins (127). p53 and p103-Rb are marked by E6 and E7 oncoproteins, but the resultant mutation is reversible (127). Hence, inhibition of these viral oncoproteins can reactivate p53 and lead to apoptosis of cervical cancer cells (128-130). The cell cycle arrest is carried out by transcriptional activation of p21 cip1/waf1 which is a cyclin dependent kinase (131); this further activates Bax, a proapoptotic gene product $(129,130)$. A study conducted on CaSKi cell line of human cervical cancer has found withaferin-A to possess the ability to downregulate oncoproteins E6 and E7 expression by HPV. This induces accumulation of p53 in tumor cells and upregulation of p21 cip1/waf1, which in turn interact with proliferating cell nuclear antigen (PCNA), leading to B1, p34 cdc2 and PCNA levelsmodulated-G2/M-cell-cycle-arrest. Another known mechanism of cervical cancer inhibition by withaferin-A includes phosphorylation of Tyr-705 and Ser-727 and STAT 3, all of which lead to altered expression of $\mathrm{BCl} 2$, Bax, Caspase 2 and cleaved PARP, which are p53 mediated apoptosis markers.

\section{Ovarian cancer}

Epithelial ovarian cancer is the fifth most leading cause of cancer deaths among American women (132, 133). Common therapeutic measures in ovarian cancer patients include cyto-reductive surgeries followed by chemotherapy using carboplatin by platinum taxane, combined with paclitaxel. Although in 70 to $80 \%$ of the cases, this treatment approach is initially effective, in over $70 \%$ of the cases, the recurrent cancer developed due to cellular platinum resistance leads to tumor relapse (134). Studies have shown that this chemo-resistance is due to cancer stem cells (135) which are one of the major causes for chemo resistance, tumor progression and relapse of the cancer, post initial treatment $(136,137)$. The most common chemotherapeutic drug cisplatin also introduces various side effects including nausea, vomiting, neurotoxicity, severe toxicity,
DNA adducts that lead to tumor suppression. A study on A2780 cell line of human orthotopic ovarian cancer tested on mice has shown a reduction of tumor upto $70-80 \%$ and total inhibition of metastasis on treatment with withaferin-A. Withaferin-A was also found to target cancer stem cell for enhanced anti tumorogenic activity with or without the combination of cisplatin. It can reduce the dosage requirement and time dependence of cisplatin by generating reactive oxygen species that lead to DNA damage, thereby reducing the tumor proliferation (141, 142). Hence, a combined chemotherapeutic treatment with cisplatin as well as withaferin-A can enhance DNA damage.

Other mechanisms of action of withaferin-A against ovarian cancer include inactivation of Akt and NF-kB leading to apoptosis, induction of Par 4, activation of caspase 3 and caspase 9 which leads to DNA damage, inhibition of HSP 90, inhibition of FOXO $3 \mathrm{a}$ and Bim, inhibition of Notch 1 and downregulation of HPV E6 and E7 oncoprotein expression.

\section{$W$. somnifera as an adjuvant during radiation and chemotherapy}

$W$. somnifera has shown the ability to proliferate or normalize stem cells. A study on $75 \%$ methanolic $W$. somnifera extract revealed its ability to increase bone marrow cellularity, reduce $\gamma$ radiation induced leucopenia, increase leukocyte count and normalize normo-chromatic erythrocytes and poly-chromatic erythrocytes ratio. $W$. somnifera can control the proliferation of tumor and hence enhance the effectiveness of radiation therapy and decrease its side effects (85).

\section{Clinical studies on anti-cancer properties of $W$. somnifera}

There are very limited pre-clinical and clinical trials conducted on herbal extracts for their claimed medicinal properties, a major reason for this is the

Table 1. Effective dosages and cancer cell line of various withanolides used in recent clinical studies

\begin{tabular}{|c|c|c|c|c|}
\hline Active compound & Dosage & $\begin{array}{c}\text { Route of } \\
\text { administration and } \\
\text { other variables of the } \\
\text { study/ host organism } \\
\text { model } \\
\end{array}$ & Cancer type/cell line & References \\
\hline \multirow[b]{2}{*}{ Various Withanolides } & $\begin{array}{l}5 \mu \mathrm{M}-\text { Withaferin A; } 20 \mu \mathrm{M}-4 \beta- \\
\text { hydroxywithanolide; } 20 \mu \mathrm{M}- \\
\text { anomanolide A }\end{array}$ & $\begin{array}{l}\text { Administered for } 48 \\
\text { hours }\end{array}$ & $\begin{array}{l}\text { MDA-MB-231, MCF-7 (Breast } \\
\text { cancer cell lines) }\end{array}$ & $(154)$ \\
\hline & $\begin{array}{l}0.24 \pm 0.01 \text { to } 11.6 \pm 1.9 \mathrm{Ag} / \mathrm{mL}- \\
\text { Withaferin } \mathrm{A} ; 0.32 \pm 0.05 \text { to } 0.47 \\
\pm 0.15 \mathrm{Ag} / \mathrm{mL}-\text { Viscosalactone } \mathrm{B}\end{array}$ & - & $\begin{array}{l}\text { MCF-7 (Breast cancer), NCI-H460 } \\
\text { (Lung cancer), HCT-116 (Colon } \\
\text { cancer), SF-268 (CNS cancer cell } \\
\text { line) }\end{array}$ & $(45)$ \\
\hline \multirow{4}{*}{ Withaferin A } & $7 \mu \mathrm{M}, 14 \mu \mathrm{M}$ and $28 \mu \mathrm{M}$ & - & SCC-4 (Oral cancer cell line) & (155) \\
\hline & $0.7 \%, 5.8 \%, 12.4 \%$ and $22.66 \%$ & $\begin{array}{l}\text { Cispatin resistant cancer } \\
\text { cell line used }\end{array}$ & SCC-4 (Oral cancer cell line) & $(155)$ \\
\hline & $4 \mathrm{mg} / \mathrm{kg}$ body weight & Female nude mice & $\begin{array}{l}\text { Estrogen dependent MCF-7, } \\
\text { Estrogen independent MDA-MB- } \\
231 \text { (Breast cancer cell line }\end{array}$ & (51) \\
\hline & $6 \mathrm{mg} / \mathrm{kg}$ body weight & - & $\begin{array}{l}\text { MiaPaCa2, BxPc3 (Pancreatic } \\
\text { cancer cell lines) }\end{array}$ & $(156)$ \\
\hline
\end{tabular}

nephrotoxicity, hepatotoxicity and myelo-supression (138-140). The mechanism of action of cisplatin involves its binding to the tumor cell DNA forming loopholes in guidelines that either exempts herbal medicines from clinical trials or lacks strict bylaws (143). For the same reason, clinical studies are also 
very limited with respect to the anticancer aspects of $W$. somnifera and its phytochemical constituents (Table 1).

One of the earliest preclinical trials for anticancer property of withaferin-A was conducted on golden Syrian hamsters with oral cancer induced by DMBA. Withaferin-A through oral intake of $20 \mathrm{mg}$ per $\mathrm{kg}$ of the host body mass for duration of 14 weeks fully cured the cancer (144). A follow up study was conducted revealing a circadian pattern of withaferin-A activity against cancer. It was found that withaferin-A showed better anticancer property on the host from 8 am to $12 \mathrm{pm}$ with $100 \%$ protection from tumor formation, whereas when the host was treated at $12 \mathrm{am}$, it only served $50 \%$ protection from tumor formation. The diurnal nature of antioxidant enzymes activity and lipid peroxidation in the host organism. Studies also showed that treatment with DMBA and withaferin-A is more effective in reduction of protein expression of $\mathrm{p} 53$ and $\mathrm{Bcl} 2$ than treatment with DMBA alone (145).

Another study was conducted on mammary carcinogenesis developing in mmtvneu mice, which was reduced by $33 \%$ with a treatment of $750 \mathrm{mg}$ of $W$. somnifera root extract per $\mathrm{kg}$ for a period of 10 months (146). An extended study used the same model but the dosage was changed to $100 \mu \mathrm{g}$ per mouse of withaferin-A alone, 3 times a week for 28 weeks and similar results were obtained with lower metastasis of the lung and lower macroscopic tumor weights (147). It was concluded that withaferin-A inhibits self-renewal of breast cancer stem cells by altering its intermediary metabolism by reducing proteins involved in TCA and glycolysis (148). The tumor stem cell machinery is also obstructed by lowering ALDH1 activity. Further studies on mammary cancer xenograft reveals that withaferin-A has the ability to downregulate the cell proliferation marker ki-67, surviving, XIAP and upregulate TUNEL positive apoptotic cell and increase the protein expression of pERK, pRSK, CHOP and DRS (149).

A clinical study on DBA/2 female mice with skin carcinogenesis initiated by 2 weeks of DMBA application along with exposure to tumor promoter 12-o-tetradecanoyl phorbol-13-acetate was given a 20 $\mu \mathrm{g}$ dose of withaferin-A once a day, 5 times a week for 14 weeks. Withaferin-A showed $100 \%$ efficacy of tumor prevention by blocking the upregulation of acetyl CoA carboxylase induced by the carcinogen. In male nude mice it was observed that 4-8 $\mu \mathrm{g}$ of withaferin-A per $\mathrm{kg}$ body weight daily for 28 days inhibited the tumor growth factor PC-3 and inhibited the activity of proteosomal chymotrypsin (123). Some studies injected withaferin-A into the host by patches as well, a patch delivering $4 \mathrm{mg}$ withaferin-A per $\mathrm{kg}$ inhibited $60 \%$ of A549 lung cancer cases (150).

Clinical studies on human test subjects on this regard are very limited. One of the recent studies conducted in International Institute of Herbal Medicine (IIHM), Lucknow, on prostate cancer, dermatofibrosarcoma, breast cancer, fibroids of uterus and squamous cell carcinoma of the penis in last stages of the cancer without conventional drug treatment when modern treatment was refused by the subjects, some of those were fully cured with $W$. somnifera extract and radiologival intervention alone (151). While side effects drastically reduced with the use of this extract as an adjuvant to traditional treatment in most of the other subjects (152).

\section{Conclusion and Future perspectives}

The present review indicates that methanolic and aqueous extracts of root and stem of $W$. somnifera shows anti-cancer activity by either induction of apoptosis, cell cycle arrest or cytotoxicity of the cancer cells. It also has the ability to control progression of cancer by inhibition metastasis and angiogenesis and can be used as an adjuvant during radiation and chemotherapy. The prominent mechanisms for its activity specifically against hepatocellular carcinoma, skin cancer, breast cancer, prostate cancer, lung cancer, colon and colorectal cancer, cervical cancer and ovarian cancer were elaborated. Some of these mechanisms are Nitric oxide synthase (NOS) upregulation and production of reactive oxygen species (ROS) leading to mutations and DNA damage or mitochondrial dysfunction and telomerase inhibition all of which cause apoptosis. Inhibition of viral oncoproteins and other immune responses and activation of p53 and pRb leading to cytotoxicity, inhibition of angiogenesis and metastasis by MDSC and STAT 3 inhibition and VEGF down regulation and cell cycle arrest caused by inhibition of transcription factor NF-kappaB. Fig. 3 gives a diagrammatic representation of all the above mentioned mechanisms of anti-cancer activity.

Although biochemical mechanisms are proposed, most of the studies are only held on animal test subjects. Anti-tumorogenic activity of $W$. somnifera is yet to be identified for various newly emerging cancer cell lines. Most of the research studies referred in this study have not proposed a definite biochemical mechanism for their findings yet. Anti-cancer activities against some cell lines have only been proposed based on molecular docking without consideration of any experiments involving test subjects. Even the pre-clinical and clinical studies conducted so far are mostly on animal test subjects. Moreover, a large number of them use withaferin-A as the therapeutic agent but not $W$. somnifera extract. It is important to understand that the plant extract is a mixture of numerous phytochemical active compounds in varying concentrations and testing the viability of withaferin-A alone doesn't give much clarity on the effect of the whole extract which is mostly consumed in reality and as a result, test result with withaferin-A must be extrapolated for the extract. Another major drawback of the previously conducted human clinical trials includes consideration of a small sample space which mostly consists of older population.

Hence in the future, studies must be conducted on human test subjects for the cell lines identified to be affected by treatment with $W$. somnifera extract. Definite mechanisms must also be proposed for cancer cell lines regulated by $W$. somnifera yet lacking a biochemical mechanism. Effect of $W$. somnifera treatment must be analyzed as a candidate 


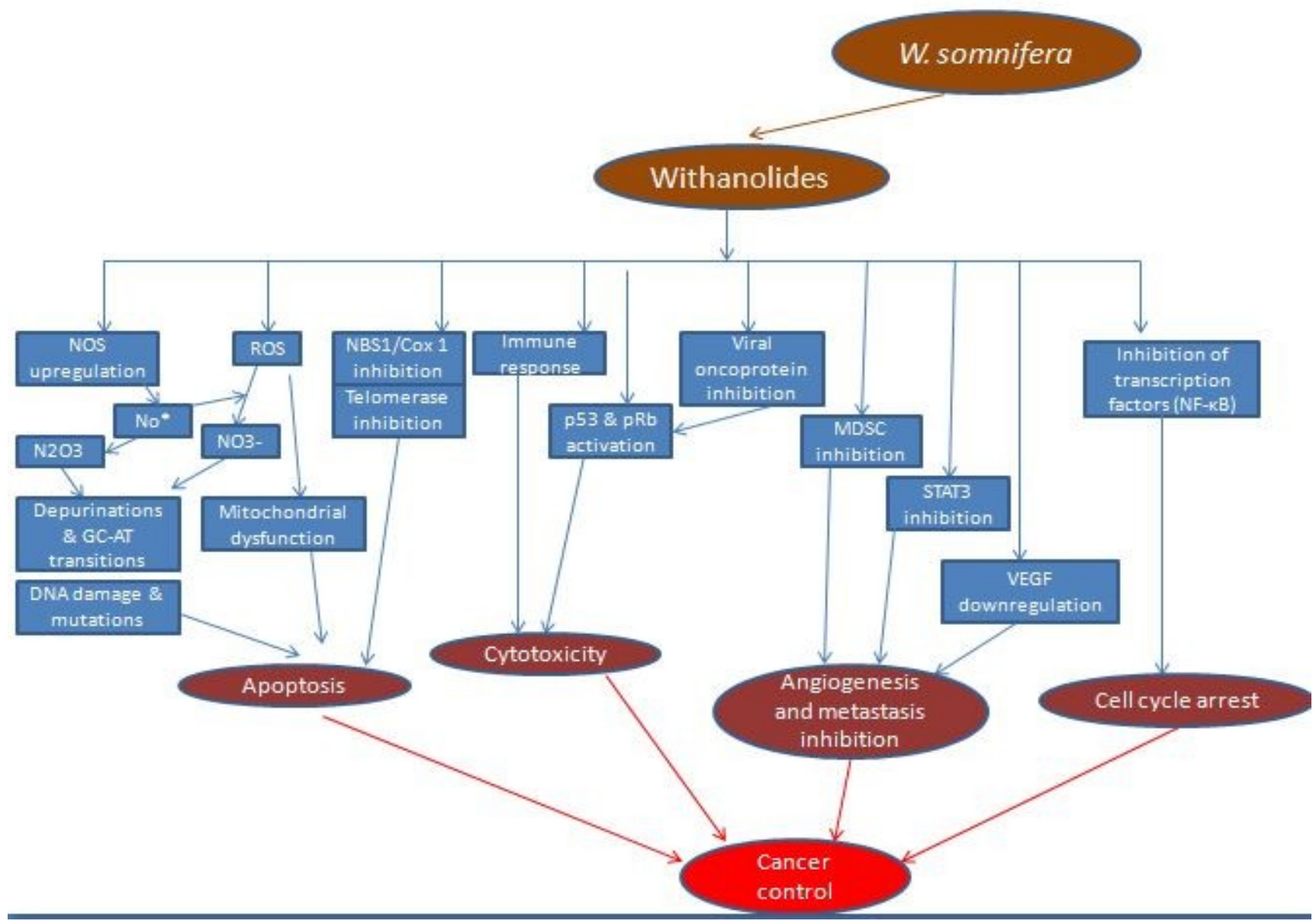

Fig. 3. Mechanism of action of withanolides in controlling cancer from Withania somnifera.

phytotherapeutic drug and a complete substitute of the conventional chemotherapeutic drugs against various cancer cell lines.

Studies have also shown various adverse effects on human consumption of $W$. somnifera including fever, rash, diarrhea, edema and abnormal LFTs (153). Further inspection on this aspect is crucial, research must also be undertaken to reduce these adverse effects.

\section{Acknowledgements}

All the authors would like to acknowledge their respective institutions for the support and encouragement. We extend our sincere thanks to Smita Dhantal, Department of English, CHRIST (Deemed to be University) for language correction. We would also like to thank everyone involved directly and indirectly in making this review possible.

\section{Authors' contributions}

RSU, PMN and PN did extensive literature survey and collected the articles. RSU wrote the review. VU and PMN helped in providing regular assistance during the process and PN was involved in finalization of the manuscript and all authors read and approved the final manuscript.

\section{Conflict of interests}

All the authors declare that there is no conflict of interest.

\section{References}

1. Maurya R, Akanksha, Jayendra. Chemistry and pharmacology of Withania coagulans: An ayurvedic remedy. J Pharm Pharmacol. 2010;62:153-60. https://doi.org/10.1211/jpp.62.02.0001

2. Jonh J. Therapeutic potential of Withania somnifera: A report on phyto pharmacological properties. Int J Pharm Sci Res. 2014;5(21):31-48. $\quad$ https://doi.org/10.13040/IJPSR.09758232.5(6).2131-48

3. Mahendra R, Priti S J, Gauravi A, Carolina AdS. Anticancer activities of Withania somnifera: Current research, formulations, and future perspectives. Pharm Biol. 2016;54(2):189-97. https://doi.org/10.3109/13880209.2015.1027778

4. Soladoye MO, Amusa NA, Raji-Esan SO, Chukwuma EC, Taiwo AA. Ethnobotanical survey of anti-cancer plants in Ogun State, Nigeria. Ann Biol Res. 2010;1(4):261-73.

5. Manju N, Shahnwaj T, Ashwani Kumar G. Enhancement in growth and yield of ashwagandha (Withania somnifera (L.) Dunal) by counteracting effect of infrared supplemented with ultraviolet-B radiation. Int J Sci Res. 2016;5(2):2209-14.

6. Bhattacharya SK, Muruganandam AV. Adaptogenic activity of Withania somnifera: An experimental study using a rat model of chronic stress. Pharmacol Biochem Behav. 2003;75(5):47-55. https://doi.org/10.1016/s0091-3057(03)00110-2

7. Widodo N, Kaur K, Shrestha B, Takagi Y, Ishii T, Wadhwa R, et al. Selective killing of cancer cells by leaf extract of Ashwagandha: identification of a tumor-inhibitory factor and the 
first molecular insights to its effect. Clin Cancer Res. 2007;13: 2298-06. https://doi.org/10.1158/1078-0432.CCR-06-0948

8. Babli H, Shruti S, Suman ST. Withania somnifera root extract has potent cytotoxic effect against human malignant melanoma cells. PLoS ONE. 2015;10(9):e0137498. https://doi.org/ 10.1371/journal.pone.0137498

9. Wadhwa R, Singh R, Gao R, Shah N, Widodo N, Nakamoto T, et al. Water extract of ashwagandha leaves has anticancer activity: Identification of an active component and its mechanism of action. PLOS ONE. 2013;8(10):e77189. https://doi.org/ 10.1371/journal.pone.0077189

10. Mishra L, Singh B, Dagenais S. Scientific basis for the therapeutic use of Withania somnifera. (Ashwagandha): A review. Altern Med Rev. 2000;5(3):34-46. PMID: 10956379.

11. Matsuda H, Murakami T, Kishi A, Yoshikawa M. Structures of withanosides I. II, III: IV, V, VI, and VII, new withanolide glycosides, from the roots of Indian Withania somnifera Dunal and inhibitory activity for tachyphylaxis to clonidine in isolated guinea-pig ileum. Bioorg Med Chem. 2001;9(1):1499-507. https://doi.org/10.1016/s0968-0896(01)00024-4

12. Bolleddula J, Fitch W, Vareed S, Nair M. Identification of metabolites in Withania sominfera fruits by liquid chromatography and high-resolution mass spectrometry. Rapid Commun Mass Spectrom. 2012;26:1277-90. https://doi.org/10.1002/rcm.6221.

13. $\mathrm{Xu} \mathrm{Y,} \mathrm{Gao} \mathrm{S,} \mathrm{Bunting} \mathrm{DP,} \mathrm{Gunatilaka} \mathrm{AAL.} \mathrm{Unusual} \mathrm{withan-}$ olides from aeroponically grown Withania somnifera. Phytochemistry. 2011;72:518-22. https://doi.org/10.1016/j.phytochem.2010.12.020

14. Chen LX, He H, Qiu F. Natural withanolides: An overview. Nat Prod Rep. 2011;28:705-40. https://doi.org/10.1039/c0np00045k

15. Ray $A B$, Gupta $M$. Withasteroids, a group of naturally occurring steroidal lactones. Prog Chem Org Nat Prod. 1994;63:1106. https://doi.org/10.1007/978-3-7091-9281-8_1

16. Kulkarni S, Singh K, Bishnoi M. Comparative behavioural profile of newer antianxiety drugs on different mazes. Indian J Exp Biol. 2008;46:633-38.

17. Mohammad HM, Elisabeth M, Mercedes B, Rosa MC, Javier P. Steroidal lactones from Withania somnifera, an ancient plant. Molecules. 2009;14:2373-93. https://doi.org/10.3390/molecules14072373

18. Uvais MSS, Sotheeswaran S, Balasubrmaniam S, El-Kawi MABD, Slatkin DJ, Schiff Jr PL. Pachyovatamine, a bisbenzylisoquinoline alkaloid and other alkaloids from Pachygone ovata. Phytochemistry. 1985;24:589-92.

19. Fazal Hussain S, Khan L, Guinaudeau H, Leet JE, Freyer AJ, Shamma M. The alkaloidal profile of Cocculus pendulus. Tetrahedron. 1984;40(13):2513-17. https://doi.org/10.1016/s00404020(01)83503-1

20. Leet JE, Hussain SF, Minard RD, Shamma M. Sindamine, punjabine and gilgitine: three new secobisbenzylisoquinoline alkaloids. Heterocycles. 1982;19:2355-60.

21. Khan PM, Ahmad S, Rubnawaz H, Malik A. The first of withanolide from the family Labiatae. Phytochemistry. 1999;51:669 71. https://doi.org/10.1016/S0031-9422(99)00045-X

22. Sever R, Brugge JS. Signal transduction in cancer. Cold Spring Harb Perspect Med. 2015;5. https://doi.org/10.1101/cshperspect.a006098

23. Aggarwal B, Ichikawa H, Garodia P, Weerasinghe P, Sethi G, Bhatt I, et al. From traditional ayurvedic medicine to modern medicine: identification of therapeutic targets for suppression of inflammation and cancer. Expert Opin Ther Targets. 2006;10(1):87-118. https://doi.org/10.1517/14728222.10.1.87

24. Hanahan D, Weinberg RA. Hallmarks of cancer: the next generation. Cell. 2011;144(5):646-74. https://doi.org/10.1016/ j.cell.2011.02.013

25. Charames GS, Bapat B. Genomic instability and cancer. Curr Mol Med. 2003;3(7):589-96. https://doi.org/ $10.2174 / 1566524033479456$

26. Szarc vel Szic K, Beeck KOd, Ratman D, Wouters A, Beck I, Declerck K, et al. Pharmacological levels of Withaferin A (With ania somnifera) trigger clinically relevant anticancer effects specific to triple negative breast cancer cells. PLoS One. 2014; 9(2):e87850. https://doi.org/10.1371/journal.pone.0087850

27. Nashi W, Yasuomi T, G. SB, Tetsuro I, C. KS, Renu W. Selective killing of cancer cells by leaf extract of Ashwagandha: Components, activity and pathway analyses. Cancer Letters. 2008;262:37-47. https://doi.org/10.1371/journal.pone.0013536

28. Alok SC, Shanker, Lalit KT, Mahendra S, Rao ChV. Herbal medicine for market potential in India. Academic Journal of Plant Sciences. 2008;1(2):26-36.

29. Shoeb M. Anticancer agents from medicinal plants. Bangladesh J Pharmacol. 2006;1:35-41. https://doi.org/10.3329/bjp.v1i2.486

30. Schmidt M, Bastians H. Mitotic drug targets and the development of novel anti-mitotic anticancer drugs. Drug Resist Updat. 2007;10:162-81. https://doi.org/10.1016/j.drup.2007.06.003

31. Dholwani KK, Saluja AK, Gupta AR, Shah DR. A review on plant - derived natural products and their analogs with anti-tumor activity. Indian J Pharmacol. 2008;40(2):49-58. https://doi.org/ 10.4103/0253-7613.41038

32. Srivastava V, Negi AS, Kumar JK, Gupta MM, Suman PS. Plantbased anticancer molecules: a chemical and biological profile of some important leads. Bioorg Med Chem. 2005;13:5892-908. https://doi.org/10.1016/j.bmc.2005.05.066

33. Grin B, Mahammad S, Wedig T, Cleland M, Tsai L, Herrmann H et al. Withaferin A alters intermediate filament organization, cell shape and behavior. PLoS ONE 7(6): e39065. 2012. https:// doi.org/ 10.1371/journal.pone.0039065

34. Shah N, Kataria H, Kaul S, Ishii T, Kaur G, Wadhwa R. Effect of the alcoholic extract of Ashwagandha leaves and its components on proliferation, migration and differentiation of glioblastoma cells: combinational approach for enhanced differentiation. Cancer Sci. 2009;100(9):1740-47. https://doi.org/ 10.1111/j.1349-7006.2009.01236.x

35. Jayaprakasam B, Padmanabhan K, Nair M. Withanamides in Withania somnifera fruit protect PC-12 cells from beta-amyloid responsible for Alzheimer's disease. Phytother Res. 2009;24:859-63. https://doi.org/10.1002/ptr.3033

36. Kuboyama T, Tohda C, Komatsu K. Neuritic regeneration and synaptic reconstruction induced by withanolide A. Br J Pharmacol. 2005;144:961-71. https://doi.org/10.1038/sj.bjp.0706122

37. Kumar P, Kumar A. Possible neuroprotective effect of Withania somnifera root extract against 3-nitropropionic acid-induced behavioral, biochemical, and mitochondrial dysfunction in an animal model of Huntington's disease. J Med Food. 2009;12(3):591-600. https://doi.org/10.1089/jmf.2008.0028

38. Llanos GG, Araujo LM, Jimenez IA, Moujir LM, Bazzocchi IL. Withaferin A-related steroids from Withania aristata exhibit potent antiproliferative activity by inducing apoptosis in human tumor cells. Eur J Med Chem. 2012;54:499-511. https:// doi.org/ 10.1016/j.ejmech.2012.05.032

39. Malik F, Singh J, Khajuria A, Suri KA, Satti NK, Singh S, et al. A standardized root extract of Withania somnifera and its major constituent withanolide-A elicit humoral and cell-mediated immune responses by up regulation of Th1-dominant polarization in BALB/c mice. Life Sci. 2007;80:1525-38. https://doi.org/ 10.1016/j.lfs.2007.01.029

40. Mirjalili MH, Moyano E, Bonfill M, Cusido R, Palazón J. Steroidal lactones from Withania somnifera, an ancient plant for novel medicine. Molecules. 2009;14:2373-93. https://doi.org/ 10.3390/molecules14072373

41. Ven Murthy MR, Ranjekar PK, Ramassamy C, Deshpande M Scientific basis for the use of Indian ayurvedic medicinal plants in the treatment of neurodegenerative disorders: Ashwagandha. Cent Nerv Syst Agents Med Chem. 2010;10(3):23846. https://doi.org/10.2174/1871524911006030238

42. Ichikawa H, Takada Y, Shishodia S, Jayaprakasam B, Nair MG Aggarwal BB. Withanolides potentiate apoptosis, inhibit invasion, and abolish osteoclastogenesis through suppression of nuclear factor-kappaB (NF-jB) activation and NF-jB-regulated gene expression. Mol Cancer Ther. 2006;5(6):1434-45. https://doi.org/ 10.1158/1535-7163.MCT-06-0096

43. Mahrous RSR, Ghareeb DA, Fathy HM, Abu EL-Khair RM, Omar AA. The protective effect of Egyptian Withania somnifera 
against Alzeheimer's. Med Aromat Plants. 2017;6:285 https://doi.org/ 10.4172/2167-0412.1000285

44. Scartezzini P, Antognoni F, Conte L, Maxia A, Troìa A, Poli F. Genetic and phytochemical difference between some Indian and Italian plants of Withania somnifera (L.) Dunal. Nat Prod Res. 2007;21(10):923-32. https://doi.org/ $10.1080 / 14786410701500169$

45. Jayaprakasam B, Zhang Y, Seeram NP, Nair MG. Growth inhibition of human tumor cell lines by withanolides from Withania somnifera leaves. Life Sci. 2003;74:125-32. https://doi.org/ 10.1016/j.lfs.2003.07.007

46. Mayola E, Gallerne C, Esposti DD, Martel C, Pervaiz S, Larue L, et al. Withaferin A induces apoptosis in human melanoma cells through generation of reactive oxygen species and downregulation of Bcl-2. Apoptosis. 2011;16:1014-27. https://doi.org/ 10.1007/s10495-011-0625-X

47. Widodo N, Priyandoko D, Shah N, Wadhwa R, Kaul SC. Selective killing of cancer cells by ashwagandha leaf extract and its component withanone involves ROS signaling.. PLOS ONE. 2010;5(10):e13536.

journal.pone.0013536

48. Davis L, Kuttan G. Effect of Withania somnifera on DMBA induced carcinogenesis. J Ethnopharmacol. 2001;75:165-68. https://doi.org/10.1016/s0378-8741(00)00404-9

49. Srinivasan S, Ranga RS, Burikhanov R, Han S, Chendil D. Par-4dependent apoptosis by the dietary compound Withaferin A in prostate cancer cells. Cancer Res. 2007;67(1):246-53. https:// doi.org/10.1158/0008-5472.CAN-06-2430

50. Oh JH, Lee T, Kim SH, Choi YH, Lee SH, Lee JM, et al. Induction of apoptosis by withaferin A in human leukemia U937 cells through down-regulation of Akt phosphorylation. Apoptosis. 2008;13:1494-04. https://doi.org/10.1007/s10495-008-0273-y

51. Stan SD, Hahm ER, Warin R, Singh SV. Withaferin A causes FOXO3a- and Bim-dependent apoptosis and inhibits growth of human breast cancer cells in vivo. Cancer Res. 2008;68(18):7661-69. https://doi.org/10.1158/0008-5472.CAN-08 1510

52. Mandal C, Dutta A, Mallick A, Chandra S, Misra L, Sangwan RS, et al. Withaferin A induces apoptosis by activating p38 mitogen- activated protein kinase signaling cascade in leukemic cells of lymphoid and myeloid origin through mitochondrial death cascade. Apoptosis. 2008;13:1450-64. https://doi.org/ 10.1007/s10495-008-0271-0

53. Kaileh M, Vanden Berghe W, Heyerick A, Horion J, Piette J, Libert C, et al. Withaferin A strongly elicits IkappaB kinase beta hyperphosphorylation concomitant with potent inhibition of its kinase activity. J Biol Chem. 2007;282:4253-64. https:// doi.org/ 10.1074/jbc.M606728200

54. Koduru S, Kumar R, Srinivasan S, Evers MB, Damodaran C. Notch-1 inhibition by Withaferin-A: a therapeutic target against colon carcinogenesis. Mol Cancer Ther. 2010;9(1):20210. https://doi.org/10.1158/1535-7163.MCT-09-0771

55. Lee J, Sehrawat A, Singh SV. Withaferin A causes activation of Notch2 and Notch4 in human breast cancer cells. Breast Cancer Res Treat. 2012;136(1):45-56. https://doi.org/10.1007/ s10549-012-2239-6

56. Mohan R, Hammers HJ, Bargagna-Mohan P, Zhan XH, Herbstritt CJ, Ruiz A, et al. Withaferin A is a potent inhibitor of angiogenesis. Angiogenesis. 2004;7:115-22. https://doi.org/ 10.1007/s10456-004-1026-3

57. Mihara M, Erster S, Zaika A, Petrenko O, Chittenden T, Pancoska P, et al. p53 has a direct apoptogenic role at the mitochondria. Mol Cell. 2003;11:577-90._https://doi.org/10.1016/ s1097-2765(03)00050-9

58. Dumont P, Leu JI, Della Pietra AC, George D, Murphy M. The codon 72 polymorphic variants of p53 have markedly different apoptotic potential. Nat Genet. 2003;33:357-65. https://doi.org/ 10.1038/ng1093

59. Wadhwa R, Yaguchi T, Hasan MK, Mitsui Y, Reddel RR, Kaul SC. Hsp70 family member, mot-2/mthsp70/ GRP75, binds to the cytoplasmic sequestration domain of the p53 protein. Exp Cell Res. 2002;274(2):246-53. https://doi.org/10.1006/excr.2002.5468
60. Wadhwa R, Kaul SC, Mitsui Y, Sugimoto Y. Differential subcellular distribution of mortalin in mortal and immortal mouse and human fibroblasts. Exp Cell Res. 1993;207(44):2-8.

61. Chahar MK, Sharma N, Dobhal MP, Joshi YC. Flavonoids: a versatile source of anticancer drugs. Pharmacogn Rev. 2011;5(9):1-12. https://doi.org/10.4103/0973-7847.79093

62. Zhang X, Samadi AK, Roby KF, Timmermann B, Cohen MS. In hibition of cell growth and induction of apoptosis in ovarian carcinoma cell lines CaOV3 and SKOV3 by natural withanolide Withaferin A. Gynecol Oncol. 2012;124:606-12. https://doi.org/ 10.1016/j.ygyno.2011.11.044

63. Zhang X, Mukerji R, Samadi AK, Cohen MS. Down-regulation of estrogen receptor-alpha and rearranged during transfection tyrosine kinase is associated with withaferin a-induced apoptosis in MCF-7 breast cancer cells.. BMC Complement Altern Med. 2011;11:84. https://doi.org/10.1186/1472-6882-11-84

64. Ram VR, Suman S, Trinath PD, Joe EL, Chendil D. Withaferin A, a steroidal lactone from Withania somnifera, induces mitotic catastrophe and growth arrest in prostate cancer cells. J Nat Prod. 2013;76:1909-15. https://doi.org/10.1021/np400441f

65. Muralikrishnan G, Dinda AK, Shakeel F. Immunomodulatory effects of Withania somnifera on azoxymethane induced experimental colon cancer in mice. Immunol Invest. 2010;39:688-98. https://doi.org/10.3109/08820139.2010.487083

66. Nagaraj S, Gabrilovich DI. Myeloid-derived suppressor cells in human cancer. Cancer J. 2010;16(4):348-53. https://doi.org/ 10.1097/PPO.0b013e3181eb3358

67. Kodumudi KN, Weber A, Sarnaik AA, Pilon-Thomas S. Blockade of myeloid-derived suppressor cells after induction of lymphopenia improves adoptive $\mathrm{T}$ cell therapy in a murine model of melanoma. J Immunol. 2012;189:5147-54. https://doi.org/ 10.4049/jimmunol.1200274

68. Ostrand-Rosenberg S. Myeloid-derived suppressor cells: more mechanisms for inhibiting antitumor immunity. Cancer Immunol Immunother. 2010;59:1593-1600. https://doi.org/ 10.1007/s00262-010-0855-8

69. Sinha P, Clements VK, Ostrand-Rosenberg S. Interleukin- 13 regulated M2 macrophages in combination with myeloid suppressor cells block immune surveillance against metastasis Cancer Res. 2005;65(24):11743-51. https://doi.org/10.1158/0008 5472.CAN-05-0045

70. Sinha P, Clements VK, Ostrand-Rosenberg S. Reduction of myeloid-derived suppressor cells and induction of M1 macrophages facilitate the rejection of established metastatic disease. J Im munol. 2005;174:636-45. https://doi.org/10.4049/ jimmunol.174.2.636

71. Christina AJM, Joseph DG, Packialakshmi M, Kothai R, Robert SJH, Chidambaranathan $\mathrm{N}$, et al. Anticarcinogenic activity of Withania somnifera Dunal against Dalton's ascitic lymphoma. J Ethnopharmacol. 2004;93:359-61. https://doi.org/10.1016/ j.jep.2004.04.004

72. Padmavathi B, Rath PC, Rao AR, Singh RP. Roots of Withania somnifera inhibit forestomach and skin carcinogenesis in mice. Evid Based Complement Alternat Med. 2005;2(1):99-105. https://doi.org/10.1093/ecam/neh064

73. Senthilnathan P, Padmavathi R, Magesh V, Sakthisekaran D. Chemotherapeutic efficacy of paclitaxel in combination with Withania somnifera on benzo(a)pyrene induced experimental lung cancer. Cancer Sci. 2006;97(7):658-64. https://doi.org/ 10.1111/j.1349-7006.2006.00224.x

74. Leyon PV, Kuttan G. Effect of Withania somnifera on B16F-10 melanoma induced metastasis in mice. Phytother Res. 2004;18:118-22. https://doi.org/10.1002/ptr.1378.

75. Wafaa Abdallah A, Mohamed A, Nasser EA, Doaa E. Potential toxicity of Egyptian ashwagandha: Significance for their therapeutic bioactivity and anticancer properties. Intl J Sci Res. 2015;4(2):2170-76.

76. Scartezzini P, Speroni E. Review on some plants of Indian traditional medicine with antioxidant activity. J Ethnopharmacol. 2000;71:23-43. https://doi.org/10.1016/s0378-8741(00)00213-0

77. Senthilnathan P, Padmavathi R, Magesh V, Sakthisekaran D. Modulation of TCA cycle enzymes and electron transport chain 
systems in experimental lung cancer. Life Sci. 2006;78:1010-14. https://doi.org/10.1016/j.lfs.2005.06.005

78. Samuel T, Okada K, Hyer M, Welsh K, Zapata JM, Reed JC. cIAP1 localizes to the nuclear compartment and modulates the cell cycle. Cancer Res. 2005;65(1):210-18. PMID: 15665297.

79. Prakash J, Gupta SK, Dinda AK. Withania somnifera root extract prevents DMBA-induced squamous cell carcinoma of skin in Swiss albino mice. Nutr Cancer. 2002;42(1):91-97. https:// doi.org/ 10.1207/S15327914NC421_12

80. Patti R, Gumired K, Reddanna P, Sutton LN, Philips PC, Reddy CD. Overexpression of cyclooxygenase-2 (COX-2) in human primitive neuroectodermal tumors: effect of celecoxib and rofecoxib. Cancer Lett. 2002;180:13-21. https://doi.org/10.1016/ s0304-3835(02)00003-4

81. Ohno R, Yoshinaga K, Fujita T, Hasegawa K, Iseki H, Tsunozaki $\mathrm{H}$, Ichikawa W, et al. Depth of invasion parallels increased cyclooxygenase-2 levels in patients with gastric carcinoma. Cancer. 2001;91(10):1876-81. PMID: 11346869.

82. Khuder SA, Mutgi AB. Breast cancer and NSAID use: a metaanalysis. Br J Cancer. 2001;84(9):1188-92. https://doi.org/ 10.1054/bjoc.2000.1709

83. Smith WL, De Witt DL, Garavito RM. Cyclooxygenases: structural, cellular, and molecular biology. Annu Rev Biochem. 2000;69:145-82.

annurev.biochem.69.1.145 https://doi.org/10.1146/

84. Jayaprakasam B, Nair MG. Cyclooxygenase-2 enzyme inhibitory withanolides from Withania somnifera leaves. Tetrahedron. 2003;59(6):841-49. https://doi.org/10.1016/S00404020(02)01601-0

85. Kaur K, Rani G, Widodo N, Nagpal A, Taira K, Kaul SC, et al. Evaluation of the anti-proliferative and anti-oxidative activities of leaf extract from in vivo and in vitro raised Ashwagandha. Food Chem Toxicol. 2004;42:2015-20. https:// doi.org/ 10.1016/j.fct.2004.07.015

86. Rajeev N, Sarita K, Parul J, Alka P. Anticancer activity of With ania somnifera (leaves) flavonoids compound. Int J Pharm Sci Rev Res. 2013;19(1):103-06.

87. Mathur S, Kaur P, Sharma M, Katyal A, Singh B, Tiwari M, et al. The treatment of skin carcinoma, induced by UV B radiation, using 1-oxo-5beta, 6beta-epoxy-witha-2-enolide, isolated from the roots of Withania somnifera, in a rat model. Phytomedicine. 2004;11:452-60. https://doi.org/10.1016/ j.phymed.2003.05.004

88. Singh D, Aggarwal A, Maurya R, Naik S. Withania somnifera inhibits NF-kappaB and AP-1 transcription factors in human peripheral blood and synovial fluid mononuclear cells Phytother Res. 2007;21:905-13. https://doi.org/10.1002/ptr.2180

89. Senthil V, Ramadevi S, Venkatakrishnan V, Giridharan P, Lakshmi BS, Vishwakarma RA, et al. Withanolide induces apoptosis in HL-60 leukemia cells via mitochondria mediated cytochrome c release and caspase activation. Chem Biol Interact. 2007;167:19-30. https://doi.org/10.1016/j.cbi.2007.01.004

90. Singh DD, Dey CS, Bhutani KK. Downregulation of p34cdc2 expression with aqueous fraction from Withania somnifera for a possible molecular mechanism of anti-tumor and other pharmacological effects. Phytomedicine. 2001;8(6):492-94.

91. Iuvone T, Esposito G, Capasso F, Izzo AA. Induction of nitric oxide synthase expression by Withania somnifera in macrophages. Life Sci. 2003;72:1617-25. https://doi.org/10.1016/s00243205(02)02472-4

92. Oza VP, Parmar PP, Kumar S, Subramanian RB. Anticancer properties of highly purified L-asparaginase from Withania somnifera L. against acute lymphoblastic leukemia. Appl Biochem Biotechnol. 2010;160:1833-40. https://doi.org/10.1007/ s12010-009-8667-z.

93. Anjaneyulu ASR, Rao DS, Le Quesne PW. Studies in natural products chemistry: Structure and chemistry (Part F). Atta-urRahman. 1998;20:135-261.

94. Dai ZJ, Wang XJ, Li ZF, Ji ZZ, Ren HT, Tang W, et al. Scutellaria barbata extract induces apoptosis of hepatoma H22 cells via the mitochondrial pathway involving caspase-3. World J Gastroenterol. 2008;14(48):7321-28. PMID: 19109865.
95. Shafik NF, Elshimy RAA, Rahouma M, Rabea AM. Circulating MiR-150 and miR-130b as promising novel biomarkers for hepatocellular carcinoma. Cancer Biol. 2017;7(2):1-8. https:// doi.org/10.7537/marscbj070217.01

96. El-Serag HB. Epidemiology of viral hepatitis and hepatocellular carcinoma. Gastroenterology. 2012;142:1264-73. https:// doi.org/ 10.1053/j.gastro.2011.12.061

97. Tejeda-Maldonado J, Garcia-Juarez I, Aguirre-Valadez J, González-Aguirre A, Vilatobá-Chapa M, Armengol-Alonso A, et al. Diagnosis and treatment of hepatocellular carcinoma: An update. World J Hepatol. 2015;7(3):362-76. https://doi.org/ 10.4254/wjh.v7.i3.362

98. Samlowski WE, Yim CY, McGregor JR, Kwon OD, Gonzales S, Hibbs Jr JB. Effectiveness and toxicity of protracted nitric oxide synthesis inhibition during IL-2 treatment of mice. J Immunother Emphasis Tumor Immunol. 1995;18(3):166-78. https:// doi.org/10.1097/00002371-199510000-00004

99. Best J, Schotten C, Theysohn JM, Wetter A, Muller S, Radunz S, et al. Novel implications in the treatment of hepatocellular carcinoma. Ann Gastroenterol. 2017;30(1):23-32. PMID: 28042235.

100. Karaman B, Battal B, Sari S, Verim S. Hepatocellular carcinoma review: Current treatment, and evidence-based medicine. World J Gastroenterol. 2014;20(47):18059-60. PMID: 25548509.

101. Njamen D, Zingue S, Mvondo MA, Magne Nde CB. The efficacy of some comestible natural products in treatment of cancer. Altern Integr Med. 2014;3:158. https://doi.org/10.4172/23275162.1000158

102. Morishima N, Nakanishi K, Takenouchi H, Shibata T, Yasuhiko Y. An endoplasmic reticulum stress-specific caspase cascade in apoptosis. Cytochrome C-independent activation of caspase-9 by caspase- 12. J Biol Chem. 2002;277(37):34287-94._https:// doi.org/ 10.1074/jbc.M204973200

103. Pretorius E, Oberholzer HM, Becker PJ. Comparing the cytotoxic potential of Withania somnifera water and methanol extracts. Afr J Tradit Complement Altern Med. 2009;6(3):275-80. https://doi.org/10.4314/ajtcam.v6i3.57173

104. Kennecke H, Yerushalmi R, Woods R, Cheang MCU, Voduc D, Speers $\mathrm{CH}$, et al. Metastatic behavior of breast cancer subtypes. J Clin Oncol. 2010;28(20):3271-77. https://doi.org/10.1200/ JCO.2009.25.9820

105. Winters M. Ancient medicine, modern use: Withania somnifera and its potential role in integrative oncology. Altern Med Rev. 2006;11(4):269-77. PMID: 17176166.

106. Newman DJ, Cragg GM. Natural products as sources of new drugs over the last 25 years. J Nat Prod. 2007;70(3):461-77. https://doi.org/ 10.1021/np068054v

107. DeSantis C, Naishadham D, Jemal A. Cancer statistics for African Americans, 2013. CA: A Cancer J Clin. 2013;63:151-66. https://doi.org/10.3322/caac.21173

108. Harris WP, Mostaghel EA, Nelson PS, Montgomery B. Androgen deprivation therapy: progress in understanding mechanisms of resistance and optimizing androgen depletion. Nature Clinical Practice Urology. 2009;6(2):76-85. https://doi.org/10.1038/ ncpuro1296

109. Nacusi LP, Tindall DJ. Targeting $5 a$-reductase for prostate cancer prevention and treatment. Nat Rev Urology. 2011;8:378-84. https://doi.org/10.1038/nrurol.2011.67

110. Sun S, Schiller JH, Gazdar AF. Lung cancer in never smokers a different disease. Nat Rev Cancer. 2007;7:778-89. https:// doi.org/ 10.1038/nrc2190

111. Bonomi PD, Finkelstein DM, Ruckdeschel JC, Blum RH, Green MD, Mason B, et al. Combination chemotherapy versus single agents followed by combination chemotherapy in stage IV nonsmall- cell lung cancer: a study of the Eastern cooperative oncology group. J Clin Oncol. 1989;7(11):1602-13. https:// doi.org/ 10.1200/JCO.1989.7.11.1602

112. Fukuoka M, Furuse K, Saijo N, Nishiwaki Y, Ikegami H, Tamura $\mathrm{T}$, et al. Randomized trial of cyclophosphamide, doxorubicin, and vincristine versus Cisplatin and Etoposide versus alternation of these regimens in small-cell lung cancer. J Natl Cancer Inst. 1991;83(12):855-61. https://doi.org/10.1093/jnci/83.12.855 
113. Said HM. Hamdard Pharmacopeia of Eastern Medicine. The Times Press, Karachi. 1970;118:477-79.

114. Jemal A, Siegel R, Ward E, Hao Y, Xu J, Thun MJ. Cancer statistics 2009. CA Cancer J Clin. 2009;59(2):225-49. https://doi.org/ 10.3322/caac.20006

115. Ferlay J, Shin HR, Bray F, Forman D, Mathers C, Parkin DM. Estimates of worldwide burden of cancer in 2008: GLOBOCAN 2008. Int J Cancer. 2010;127:2893-17. https://doi.org/10.1002/ ijc. 25516

116. Abubaker K, Luwor RB, Escalona R, McNally O, Quinn MA, Thompson EW, et al. Targeted disruption of the JAK2/STAT3 pathway in combination with systemic administration of paclitaxel inhibits the priming of ovarian cancer stem cells leading to a reduced tumor burden. Front Oncol. 2014;4:75,1-12. https://doi.org/ 10.3389/fonc.2014.00075

117. Corvinus FM, Orth C, Moriggi R, Tsareva SA, Wagner S, Pfitzner EB, et al. Persistent STAT3 activation in colon cancer is associated with enhanced cell proliferation and tumor growth. Neoplasia. 2005;7(6):545-55. https://doi.org/10.1593/neo.04571

118. Lin Q, Lai R, Chirieac LR, Li C, Thomazy VA, Grammatikakis I, et al. Constitutive activation of JAK3/STAT3 in colon carcinoma tumors and cell lines: inhibition of JAK3/STAT3 signaling induces apoptosis and cell cycle arrest of colon carcinoma cells Am J Pathol. 2005;167(4):969-80. https://doi.org/10.1016/S00029440(10)61187-X

119. Aggarwal BB, Kunnumakkara AB, Harikumar KB, Gupta SR, Tharakan ST, Koca C, et al. Signal transducer and activator of transcription-3, inflammation, and cancer: how intimate is the relationship? Ann N Y Acad Sci. 2009;1171:59-76. https:// doi.org/ 10.1111/j.1749-6632.2009.04911.x

120. Podolak I, Galanty A, Sobolewska D. Saponins as cytotoxic agents: a review. Phytochem Rev. 2010;9(3):425-74. https:/ doi.org/10.1007/s11101-010-9183-Z

121. Zhao M, Jiang B, Gao FH. Small molecule inhibitors of STAT3 for cancer therapy. Curr Med Chem. 2011;18(26):4012-18. https://doi.org/10.2174/092986711796957284

122. Bhattacharya SK, Satyan KS, Ghosal S. Antioxidant activity of glycowithanolides from Withania somnifera. Indian J Exp Biol. 1997;35(3):236-39. PMID: 9332168

123. Yang H, Shi G, Dou QP. The tumor proteasome is a primary target for the natural anticancer compound withaferin A isolated from "Indian winter cherry". Mol Pharmacol. 2007;71(2):42637. https://doi.org/10.1124/mol.106.030015

124. Munagala R, Kausar H, Munjal C, Gupta RC. Withaferin A induces p53-dependent apoptosis by repression of HPV oncogenes and upregulation of tumor suppressor proteins in human cervical cancer cells. Carcinogenesis. 2011;32(11):1697 705. https://doi.org/10.1093/carcin/bgr192

125. Clifford GM, Smith JS, Plummer M, Munoz N, Franceschi S. Human papilloma virus types in invasive cervical cancer worldwide: a meta-analysis. Br J Cancer. 2003;88:63-73. https:// doi.org/ 10.1038/sj.bjc.6600688

126. Godefroy N, Lemaire C, Mignotte B, Vayssière JL. p53 and Retinoblastoma protein (pRb): a complex network of interactions. Apoptosis. 2006;11:659-61. https://doi.org/10.1007/s10495-0065543-y

127. Scheffner M, Münger K, Byrne JC, and Howley PM. The state of the p53 and retinoblastoma genes in human cervical carcinoma cell lines. Proc Natl Acad Sci. USA. 1991;88:5523-27. https://doi.org/10.1073/pnas.88.13.5523

128. Abdulkarim B, Sabri S, Deutsch E, Chagraoui H, Maggiorella L, Thierry J, et al. Antiviral agent Cidofovir restores p53 function and enhances the radiosensitivity in HPV-associated cancers. Oncogene. 2002;21:2334-46. https://doi.org/10.1038/ sj.onc. 1205006

129. Bossi G, Sacchi A. Restoration of wild-type p53 function in human cancer: relevance for tumor therapy. Head Neck 2007;29(3):272-84. https://doi.org/10.1002/hed.20529

130. Goodwin EC, DiMaio D. Repression of human papillomavirus oncogenes in HeLa cervical carcinoma cells causes the orderly reactivation of dormant tumor suppressor pathways. Proc Nat Acad Sci. USA. 2000;97(23):12513-18. https://doi.org/10.1073/ pnas.97.23.12513
131. Ravizza R, Gariboldi MB, Passarelli L, Monti E. Role of the p53/p21 system in the response of human colon carcinoma cells to Doxorubicin. BMC Cancer. 2004;4:92. https://doi.org/ 10.1186/1471-2407-4-92

132. Siegel R, Naishadham D, Jemal A. Cancer statistics, 2013. CA Cancer J Clin. 2013;63:11-30. https://doi.org/10.3322/caac.21166

133. Hunn J, Rodriguez GC. Ovarian cancer: etiology, risk factors and epidemiology. Clin Obstet Gynecol. 2012;55(1):3-23. https://doi.org/ 10.1097/GRF.0b013e31824b4611

134. Matsuo K, Lin YG, Roman LD, Sood AK. Overcoming platinum resistance in ovarian carcinoma. Expert Opin Investig Drugs. 2010;19(11):1339-54. $10.1517 / 13543784.2010 .515585$

https://doi.org

35. Bonnet D, Dick JE. Human acute myeloid leukemia is organized as a hierarchy that originates from a primitive hematopoietic cell. Nat Med. 1997;3(7):730-37. https://doi.org/10.1038/ nm0797-730

136. Dean M, Fojo T, Bates S. Tumour stem cells and drug resist ance. Nat Rev Cancer. 2005;5:275-84. https://doi.org/10.1038/ nrc1590

137. Hermann PC, Huber SL, Heeschen C. Metastatic cancer stem cells: a new target for anti-cancer therapy?. Cell Cycle. 2008;7(2):188-93._https://doi.org/10.4161/cc.7.2.5326

138. Kintzel PE. Anticancer drug-induced kidney disorders. Incidence, Prevention and Management. Drug Saf. 2001;24(1):19-38 https://doi.org/10.2165/00002018-200124010-00003

139. El-Awady ESE, Moustafa YM, Abo-Elmatty DM, Radwan A. Cisplatin induced cardiotoxicity: Mechanisms and cardioprotective strategies. Eur J Pharmacol. 2011;650:335-41. https:// doi.org/ 10.1016/j.ejphar.2010.09.085

140. Lieberthal W, Triaca V, Levine J. Mechanisms of death induced by cisplatin in proximal tubular epithelial cells: apoptosis vs. necrosis. Am J Physiol. 1996;270(4):700-08. https://doi.org/ 10.1152/ajprenal.1996.270.4.F700

141. Kakar SS, Jala VR, Fong MY. Synergistic cytotoxic action of cis platin and withaferin A on ovarian cancer cell lines. Biochem Biophys Res Commun. 2012;423:819-25. https://doi.org/ 10.1016/j.bbrc.2012.06.047

142. Lee TJ, Um HJ, Min DS, Park JW, Choi KS, Kwon TK. Withaferin A sensitizes TRAIL-induced apoptosis through reactive oxygen species-mediated up-regulation of death receptor 5 and downregulation of c-FLIP. Free Radic Biol Med. 2009;46:1639-49. https://doi.org/10.1016/j.freeradbiomed.2009.03.022

143. Parveen A, Parveen B, Parveen R, Ahmad S. Challenges and guidelines for clinical trial of herbal drugs. J Pharm Bioall Sci. 2015;7:329-33. https://doi.org/10.4103/0975-7406.168035

144. Manoharan S, Panjamurthy K, Pugalendi P, Balakrishnan S, Rajalingam K, Vellaichamy L, et al. Protective role of withaferin-A on red blood cell integrity during 7,12-dimethylbenz[A]anthracene induced oral carcinogenesis. Afr J Trad CAM. 2010;6(1):94102. https://doi.org/10.4314/ajtcam.v6i1.57079

145. Panjamurthy K, Manoharan S, Nirmal MR, Vellaichamy L. Protective role of Withaferin-A on immunoexpression of p53 and bcl-2 in 7,12-dimethylbenz(a)anthracene-induced experimental oral carcinogenesis. Invest New Drugs. 2009;27:447-52. https://doi.org/10.1007/s10637-008-9199-Z

146. Khazal KF, Hill DL, Grubbs CJ. Effect of Withania somnifera root extract on spontaneous estrogen receptor-negative mammary cancer in MMTV/Neu mice. Anticancer Res. 2014;34(11):6327-32. PMID: 25368231.

147. Hahm ER, Lee J, Kim SH, Sehrawat A, Arlotti JA, Shiva SS, Bhargava $\mathrm{R}$, et al. Metabolic alterations in mammary cancer prevention by withaferin $A$ in a clinically relevant mouse model. J Natl Cancer Inst. 2013;105:1111-22. https://doi.org/10.1093/ jnci/djt153

148. Kim SH, Singh SV. Mammary cancer chemoprevention by withaferin $\mathrm{A}$ is accompanied by in vivo suppression of self-renewal of cancer stem cells. Cancer Prev Res. 2014;7(7):738-47. https://doi.org/10.1158/1940-6207.CAPR-13-0445

149. Nagalingam A, Kuppusamy P, Singh SV, Sharma D, Saxena NK. Mechanistic elucidation of the antitumor properties of 
withaferin A in breast cancer. Cancer Res. 2014;74:2617-29. https://doi.org/10.1158/0008-5472.CAN-13-2081

150. Gupta RC, Bansal SS, Aqil F, Jeyabalan J, Cao P, Kausar H, et al. Controlled-release systemic delivery - a new concept in cancer chemoprevention. Carcinogenesis. 2012;33(8):1608-15. https://doi.org/10.1093/carcin/bgs209

151. Singh N, Gilca M. Herbal Medicine - Science embraces tradition - a new insight into the ancient Ayurveda. Lambert Academic Publishing (Germany). 2010:51-67.

152. Singh N, Bhalla M, de Jager P, Gilca M. An Overview on Ashwagandha: A Rasayana (Rejuvenator) of Ayurveda. Afr J Tradit Complement Altern Med. 2011;8(S):208-13. https://doi.org/ 10.4314/ajtcam.v8i5S.9

153. Pires N, Gota V, Gulia A, Hingorani L, Agarwal M, Puri A. Safety and pharmacokinetics of Withaferin A in advanced stage high grade Osteosarcoma: A phase I trail. J Ayurveda Integr Med. 2019. https://doi.org/10.1016/j.jaim.2018.12.008
154. Wang HC, Tsai YL, Wu YC, Chang FR, Liu MH, Chen WY, et al. Withanolides-induced breast cancer cell death is correlated with their ability to inhibit heat protein 90. PLoS ONE. 2012;7(5):e37764.

155. Yin X, Yang G, Ma D, Su Z. Inhibition of cancer cell growth in cisplatin-resistant human oral cancer cells by withaferin-A is mediated via both apoptosis and autophagic cell death, endogenous ROS production, G2/M phase cell cycle arrest and by targeting MAPK/RAS/RAF signalling path. J BUON. 2020;25(1):332-37 PMID: 32277651.

156. Yu Y, Hamza A, Zhang T, Gu M, Zou P, Newman B, et al. Withaferin A targets heat shock protein 90 in pancreatic cancer cells. Biochem. 2010;79(4):542-51. https://doi.org/10.1016/ j.bcp.2009.09.017 